\title{
Refugee Students in the Third World
}

\section{by Paul McCarthy}

It has been said that if a Third World government wishes to maintain its grip on power, it must ensure the happiness of two sectors of the population: the soldiers and the students. Military coups are, of course, dismayingly commonplace. Student-instigated rebellions have also led to the overthrow of various Third World regimes, as happened in Thailand in the early 1970's. Indeed, university campuses in most developing nations have traditionally served as hotbeds of social unrest. The comparatively complacent Canadian student populace would no doubt be amazed at the level of political activity which exists among the student bodies of most of the universities in the Third World. But the price which the academic communities of the Third World have paid for this political and social awareness has been a high one. As a precautionary first step, many Third World governments shut down all post-secondary institutions at the first indication of any impending civil strife. In some countries, such as El Salvador, universities and technical institutes have been closed for years. The consequences are much more serious when a student body shakes but cannot topple a regime, as happened in Zaire in the late 1970's and Uganda last year. Government retribution against student activists who do not toe the government line is typically swift and merciless. Amnesty International reports that thousands of students and faculty have been illegally detained or imprisoned in Third World countries. Torture and murder are not uncommon.

For those student activists who are lucky enough to avoid imprisonment during government crackdowns, the only path open to them is self-imposed exile in a neutral country. Since they are fleeing from a well-founded fear of persecution, these students, once outside their homeland, are bona fide refugees.

It is impossible to estimate how many student refugees there are in the world today. Indeed, no statistics are kept. The sad fact of the matter is: once a refugee, no longer a student. Most educational institutions in the usual countries of first asylum, however generous in their efforts to accomodate refugee students, are hopelessly overcrowded. Moreover, there is often a resentment of refugee students on the part of local students when they are given places at institutions in their country of first asylum.

The international response to the plight of student refugees has been largely ineffective. While the UNHCR, principally through its Education and Counselling Section, has made laudable attempts at helping student refugees continue their studies, it cannot possibly hope to assist all of those in need.

Until recently, all such efforts in Canada have taken place on a strictly ad hoc basis. In 1979 the World University Service of Canada (WUSC), the Canadian affiliate of an international nongovernment organization with head- quarters in Geneva, took on the task of trying to mobilize the resources of the Canadian academic community in an effective response to the problem of student refugees. WUSC is actively attempting to open up educational opportunities for student refugees at universities and community colleges throughout the country. Once such opportunties do become available, WUSC facilitates the private sponsorship of qualified student refugees thereby allowing them to come to Canada as landed immigrants and resume their studies. Working in close cooperation with the Ministry of Immigration, the UNHCR and Canadian post-secondary institutions, WUSC has been able to sponsor and place twentyfive student refugees, the majority of whom are African, at universities and colleges from Halifax to Victoria; and WUSC hopes to make the Canadian response to the plight of student refugees increasingly effective.

In the long run, it is important to bear in mind that this kind of refugee support work is not merely a humanitarian effort - it is also a potentially important factor in the long-term development prospects of the developing countries.

For further information on the WUSC Student Refugee Programme, you are invited to contact:

World University Service of Canada P.O. Box 3000, Station "C" Ottawa, Ontario K1Y 4M8

\section{Vancouver Coalition with World Refugees}

The Vancouver Coalition with World Refugees is a group of citizens who are volunteering their time and efforts to help refugees.

Founded in 1982, the Coalition seeks to bring together churches, agencies, service clubs and individuals to undertake the following tasks:

1. To help organize sponsorship groups to bring refugees to Canada;

2. To assist newly-arrived refugees already living in the Vancouver area;
3. To help send aid to refugee camps in foreign countries;

4. To collect and spread information about refugees and urge our government to do what it can to help.

There are no fees or dues required to be a member of the Coalition. A person can be as active a member as he/she desires. Meetings take place on the fourth Wednesday of every month at 7:30 p.m. at 1410 West 12th Avenue, Vancouver,

B.C. For more information, feel free to phone:

Annie Krasker
Orval Chapman
Dr. John Conway
(Chairman)

Vancouver Coalition with World Refugees

1410 West 12th Ave. Vancouver, B.C.

V6R $1 \mathrm{M} 8$

(604) 736-1613 